\title{
Formindskede bøger i jødisk religion
}

\section{Om størrelsens betydning for mediering af religion og religiøsitet ${ }^{1}$}

\author{
MARIANNE SCHLEICHER
}

ENGLISH ABSTRACT: The size of religious books matters to how religion and religiosity has been mediated up through history, not only the history of religion, but also the history of the book. The purpose of this article is to offer a functional approach to how size, especially small size, comes to matter in religious medialization. To be able to treat miniaturized books as a religious phenomenon, the article offers a comparative, brief trajectory of developments in book formats and writing/typing techniques that detects a development towards smallness. From here, it proceeds to analyzing and reflecting on miniaturized religious books in Judaism. It goes into details with the functional aspects in the use of community rules, prayer books, Book of Psalms, haggadot shel pesach, Purim-scrolls, Hebrew Bibles and Torot. The article conjoins the author's own distinction between the hermeneutical and artifactual use of scripture with theoretical reflections by Claude Lévi-Strauss, Jonathan Z. Smith, Danièle Dehouve, Steven J. Gores, and Ian Reader. This platform has explanatory potential with regard to explaining how the small size of religious books in Jewish religion has come to matter to the medialization of religion and religiosity.

DANSK RESUME: Religiøse bøgers størrelse har betydning for, hvordan jødisk religion og jøders religiøsitet er blevet medieret op gennem historien - ikke kun religionshistorien, men også boghistorien. Artiklens formål er at tilbyde en funktionel forklaring af, hoilken betydning størrelsen, især liden størrelse, har for denne mediering. For at sikre at formindskede bøger behandles som et religiøst fænomen, tager artiklen afsæt $i$ en komparativ, kort redegørelse for udvikling i bogformater og skrive-/printteknikker for at analysere og reflektere over formindskede, religiøse bøger i jødedommen. Særligt gennemgås funktionelle aspekter ved brugen af menighedsregler, bønnebøger, udgaver af Salmernes Bog, påske-aggadot, Purim-ruller, hebræiske bibler og Torahruller. Teoretisk sammenstilles forfatterens egen skelnen mellem hermeneutisk og artefaktisk helligtekstbrug med overvejelser hos Claude Lévi-Strauss, Jonathan Z. Smith, Danièle Dehouve,

1 Denne artikel er min oversættelse og bearbejdning af min engelsksprogede artikel “On the Functions of Miniaturizing Books in Jewish Religion", der dels er udgivet i tidsskriftet Postscripts (2013) 9.2-3, 114-138, dels i Kristina Myrvold \& Dorina Miller Parmenter, eds., Miniature Books: The Format and Function of Tiny Religious Texts, Sheffield: Equinox 2019, 22-44. 
Steven J. Gores og Ian Reader. Den sammenstilling muliggør en forklaring af måden, hvorpå religiøse bøgers størrelse er af betydning for mediering af religion og religiøsitet.

KEY WORDS: Miniaturization; medialization; Jewish miniature books; book history; scripture; sacred texts; hermeneutics; artefacts

\section{Indledning}

Religiøse bøgers størrelse har betydning for, hvordan jødisk religion og jøders religiøsitet er blevet medieret op gennem historien - ikke kun religionshistorien, men også boghistorien. I den forbindelse skriver artiklen sig ind i et relativt uberørt felt inden for både judaistik og religionsvidenskab, hvor religiøse bøger, især helligtekster, primært er blevet betragtet som medium for en religiøs kommunikation, men sjældent som genstande, der har kunnet mediere andet end tekstligt indhold. For at få greb om dette 'andet' lægges der i artiklen vægt på, hvordan helligtekstbrug ofte indbefatter en aktivering af sanserne, som er styrende for brugernes orientering, associationer og sindstilstande. Forfatterens skelnen mellem hermeneutisk og artefaktisk helligtekstbrug vil sammen med teorier om formindskelse af Claude Lévi-Strauss, Jonathan Z. Smith, Danièle Dehouve, Steven J. Gores og Ian Reader blive inddraget undervejs i en analyse af konkret brug af menighedsregler, bønnebøger, Salmernes Bog, påskeaggadaher, purim-ruller samt hebræiske bibler og udgaver af Mosebøgerne. Analysen har til formål at undersøge og diskutere størrelsens funktion for religiøse bøger uanset format i jødisk religionshistorie.

\section{Samlerlitteraturens viden om formindskelse af bøger}

Et af de få steder, hvor der allerede er reflekteret over størrelsens betydning for bøger, er i samlerverdenen med dens fascination af små bøger af høj æstetisk kvalitet. Nogle af de mest informative blandt disse udgivelser foreligger i Miniature Book News and Antique E Collecting Magazine eller som online præsentationer på Miniature Book Societys hjemmeside (MBS Presentations n.d.). Siden fremkomsten af Johannes Gutenbergs trykkepresse omkring år 1440 og dermed trykte bøger i en vestlig kontekst har typesættere, bogtrykkere og bogbindere såvel som kunstnere, heriblandt Joan Miró og Pablo Picasso, udnyttet muligheden for at udfordre deres håndværksmæssige evner ved at skabe værker i et ekstremt lille format og dermed demonstrere deres kunnen. På den måde tiltrækker vestlige såkaldte miniaturebøger sig en opmærksomhed, der fokuserer på producenterne og for så vidt også samlernes evne til at genkende og værdsætte højt kvalitetsarbejde. Til tider har indledende refleksioner over årsager til miniaturebøgers eksistens suppleret det dominerende fokus på størrelse og æstetik. Her forklarer samlerlitteraturen typisk miniaturebøgers produktion og brug med henvisning til deres bærbarhed og dermed brugernes lette adgang til bøgernes tekstlige indhold (Bondy 1981, 1-3; Bromer 1988, 88). Jeg vil argumentere for med udgangspunkt i eksempler fra jødisk religion, at bøger er aldrig blot tekstbeholdere. De 
er også altid artefakter med en eller anden symbolsk funktion. Når Bondy og Bromer således understreger, at miniaturebøgernes bærbarhed muliggør den lette adgang til det tekstlige indhold, vil jeg tilføje, at miniaturebøgers bærbarhed ligeledes muliggør en let adgang til deres artefaktiske aspekter.

Samlernes fokus på størrelse og æstetik påvirkede den tidlige akademiske forskning i miniaturebøger. Doris Varner Welsh, der skrev det senere meget refererede værk The History of Miniature Books, udgivet i 1987 efter hendes død, havde en professionel viden om bøger qua sit arbejde som arkivar og udgiver af historisk og etnografisk materiale på Newberry Library i Chicago. Hun fattede interesse for miniaturebøger og samlede, typesatte og trykte en del (Rickard 1988). Welshs History of Miniature Books udmærker sig ved sin systematiske, historisk-kritiske tilgang, omend også den begynder med at redegøre for størrelseskriterier, der er så vigtige for samlerne. Ifølge Welsh fordres det af en miniaturebog, at den ikke er større end 4 tommer/ca. 10 centimeter på nogen af dens leder. Her afviger hun fra nordamerikansk standard, hvor miniaturebøger ikke må overstige 3 tommer/ca. 7,5 centimeter (Welsh 1987, 10). Welsh påpeger, at størrelseskriterierne understreger, hvordan miniaturebøger har deres oprindelse i Vesten og i de teknologiske muligheder, der fulgte med Gutenbergs trykkepresse (Welsh 1987, i). I denne artikels studie af formindskede bøger bliver det hurtigt klart, at disse størrelseskriterier forholder sig til og privilegerer kodeksformatet, som primært har været anvendt ved produktion af religiøse tekster i relativt unge religioner så som kristendom og islam. Om end det ikke er mit formål at argumentere for nye størrelseskriterier, finder jeg kodeksformatet problematisk, fordi de dertilhørende størrelseskriterier skygger for indsigter i formindskede bøger, der er blevet produceret ved hjælp af andre trykketeknologier så som litografi, der har været udbredt uden for Europa, eller i andre formater så som lertavler, bogruller eller pothi (se nedenfor). En inddragelse af andre trykketeknologier og formater kunne bidrage til at etablere et komparativt perspektiv på funktionen af formindskede religiøse bøger i religionshistorien generelt. Førend jeg indsnævrer mit fokus på formindskede religiøse bøgers medierende funktion i jødisk religion og spørger til, hvordan størrelse har betydning i denne specifikke kontekst, vil jeg inkludere viden om formindskelse af andre bogformater end kodekset og om, hvordan hvert enkelt format har specifikke medierende funktioner. I den forbindelse skal jeg kort bringe nogle eksempler fra boghistorien.

\section{Tidligt bærbare tekster i boghistorien}

Mesopotamiske lertavler fra ca. 2500 f.v.t. med delvist syllabiske inskriptioner, kendt som kileskrift, regnes for de tidligste eksempler på bøger. De mindste blandt disse tavler måler kun 2 × 2 centimeter. Lertavler blev primært brugt til at føre regnskab med og til at udstede kvitteringer i takt med, at Nærøstens landbrugskultur udviklede sig til også at indbefatte handel med afgrøder. Umiddelbart herefter begynder lertavler også at anvendes til kulturelle narrativer og kodekser så som Enuma Elish og Hammurabis Lov (Robson 2009, 68-71; Anderson and Levoy 2002; Kallendorf 2013, 40). 
I løbet af de følgende totusinde år i det østlige middelhavsområde suppleres lertavler med nye formater, nemlig metalplader og vokstavler i træ såvel som papyrus- og pergamentruller. Ruller har den åbenlyse fordel sammenholdt med tavler, at de kan anvendes til opbevaring af uafbrudte narrativer og argumenter, ligesom de er nemmere at bære og håndtere (Roemer 2009, 84; Kallendorf 2013, 41). I det første århundrede e.v.t. udviklede sammenbundne vokstavler sig i træ til kodekset, som hurtigt vandt udbredelse og blev det dominerende format i det mediterrane område. Medlemmer af en jødisk sekt, senere kendt som de kristne, erstattede allerede i det 2 . århundrede e.v.t. rulleformatet med kodeksformatet som deres foretrukne medium til opbevarelse af vigtigt fortællestof og centrale argumenter (Pearson 2013, 246). Kodeksets mange fordele forklarer dets popularitet: Kodeksets standardstørrelse er oftest mindre end standardstørrelsen på en rulle, og kodekset forøger dermed den lethed, hvormed bøger kan bæres og håndteres. Et kodeks er billigere at producere end en rulle, fordi man i et kodeks kan skrive på begge sider af kodeksets ark. Vigtigst er det dog, hvordan kodeksformatet revolutionerede den lethed, hvormed man kunne orientere sig i en bog ved at bladre frem og tilbage i dens sider og således hurtigt vende tilbage til eller sammenligne udsagn, herunder kritisk reflektere over længere argumenter og mulige inkonsistenser. På den måde faciliterer kodeksformatet diskussioner og problematiseringer af normative trosopfattelser og beskrevne praksisformer i højere grad, end ruller gør, hvilket gav grobund for både konsensusbaserede justeringer af tro og praksis i eksisterende religioner såvel som for fremkomsten af et stigende antal nye religioner. Det ældste kendte papyruskodeks er et fragment fra Johannesevangeliet, kapitel 18. Det dateres til mellem det 2. og 3. århundrede e.v.t. og kendes som Ryland-papyrus P52. Dette papyruskodeks måler blot 9 x 6 centimeter (Nongbri 2005, 46).

Mellemøsten inklusiv det østlige middelhavsområde var ikke ene om at producere bøger. Silkeruller er blevet produceret i Kina siden det 7. århundrede f.v.t. Hertil kommer, at silkeformatet blev suppleret af jiance- og pothi-formatet i det asiatiske område, der med deres plantebaserede skriveoverflader var nemmere og billigere at producere end silkeruller. En jiance-bog består af tynde bambus- og træstrimler, der holdes sammen af parallelle bånd, mens pothi-bogen består af palmebladsstrimler, der holdes sammen af snore i den ene ende, der så igen monteres i et træomslag. Det var i kontekst af kinesisk skriveteknologi, at papiret blev opfundet. I et kinesisk dokument fra 105 e.v.t. omtales papir for første gang som en konkurrent til silke som en skriveoverflade (Edgren 2013, 575). Papiret, der i forhold til silke og plantebaserede materialer var mindre omkostningstungt og nemmere at producere og bære, blev hurtigt udbredt i Asien. Papiret som ny skriveoverflade ledte også til udviklingen af koncertinaformatet i det 7. århundrede e.v.t., hvor rektangulære papirark foldes eller limes sammen i skiftevis den ene og den anden ende (Pearson 2013, 247-249). Papir var netop den foretrukne skriveoverflade, da den japanske kejserinde Shotoku i 770 e.v.t. befalede, at en buddhistisk bønneamulet skulle trykkes med kinesiske bogstaver ved hjælp af et metalpladestik, så hun kunne udtrykke sit tilhørsforhold til buddhismen gennem donation af en million kopier til ti forskellige templer. Faktisk er dette det 
tidligste ekstante eksempel på, at noget er blevet trykt på papir. Det blev trykt i rulleformat og målte 5,7 x 47 centimeter. Apropos moderne vestlige miniaturestandarder kvalificerer Kejserinde Shotokus bønneamulet sig som en miniaturebog i højden, men jo langt fra i længden, om end ingen vil betvivle rullens lidenhed (Edison 1967, 1-2; Hunter 1943, 64-76; Znidersic 2004, 144-146). Mellemamerika bør også nævnes. Uafhængigt af asiatisk praksis udviklede papirproduktion sig i klassisk mayakultur i løbet af det 1. årtusinde e.v.t. For mayafolket muliggjorde papir billige og lette skriveoverflader til deres glyffer og avancerede tal- og kalendersystemer (Vera 2013, 656657). I middelhavsområdet kendte man ikke til papir førend det 9 . århundrede.

Trykkehistorien skal kort inddrages for to vigtige observationer. Tidlige indgraveringer og tryk i metal, ler eller voks fordrede et vist pres på skriveredskabet, herunder griflen. Da de hårde skriveoverflader imidlertid blev afløst af plantebaserede skriveoverflader i både Asien og det mediterrane område fra det 3. årtusinde og frem, kunne flydende blæk bruges til inskription og muliggjorde meget hurtigere skriveteknikker. Ligeledes har den teknologiske udvikling fra træsnitstryk i Kina fra ca. 200 e.v.t. til nutidens fotografiske og elektroniske gengivelser muliggjort gradvist hurtigere duplikering, fotoreduktion og først og fremmest massedistribution.

Formålet med ovennævnte eksempler fra boghistorien er at uddrage den indsigt, at tidlige skrifter i lille format tjente som bærbare eksterne hukommelseslagre ${ }^{2}$ for handelstransaktioner, religiøst fortællestof og argumentation. Hvis man forfølger formaternes udvikling, er der en klar tendens til at formindske formater ikke blot for at økonomisere både indsats og omkostninger ved produktionen, men også for at reducere vægt for at øge en bogs bærbarhed og hurtig orientering i den. Inddrager vi metoder til alfabetisk inskription på skriveoverflader, antyder udviklingen også en rettethed mod øget tempo og let duplikation og distribution. I resten af artiklen vil disse udviklinger i boghistorien udgøre en vigtig kontekst for at forstå, hvordan bøgers størrelse, især deres lidenhed, har haft betydning for mediering af religion og religiøsitet.

\section{Teoretiske refleksioner over formindskelse generelt}

I det følgende vil jeg sammenstille forskellige teorier om formindskelse for at forklare formindskelse af religiøse bøger og formindskelsens funktioner. Jeg vil indlede med at opsummere min egen skelnen mellem hermeneutisk og artefaktisk helligtekstbrug, fordi formindskede bøger, især religiøse bøger, altid er både tekster og genstande. Nogle gange retter helligtekstbrugere deres opmærksomhed mod tekstens forslag til religiøs livsanskuelse og overvejer, om de skal tilegne sig det, transformere det eller afvise det. Dette hermeneutiske aspekt har en åbenlys dis-/identifikatorisk funktion.

2 Især Jan Assmann (fx 2004, 34) er kendt for at have pointeret, hvordan den kulturelle evolution fra mundtlighedskultur til skriftlighedskultur med dertilhørende fremkomst af nye kommunikationsmedier sikrede lagring af information uden for menneskets hukommelse og dermed frisatte kognitiv kapacitet, der så kunne anvendes bl.a. på stillingtagen til de normer, der var indskrevet i kulturens narrativer, som specialisterne hidtil havde haft monopol på at tilgå og formidle (Assmann 2004, 131. 154). 
Samtidig eller til andre tider er det selve den sanseaktiverende og derpå associationsskabende håndtering af helligteksten som en fysisk genstand, der transformerer den til en 'hub', der etablerer forbindelser i alle retninger. Hertil hører, at manipulation af genstanden vil kunne mediere, at brugeren med eller mod sin vilje bevæges ind i nye forbindelsesnetværk, der har betydning for hans eller hendes religiøsitet. Endelig skal det også her kort nævnes, at en af de sanser, der primært aktiveres i den artefaktiske brug er følesansen, hvor man fra neurologisk forskning ved, at blid berøring aktiverer udløsning af hjernens signalstoffer serotonin og dopamin, der fremmer et menneskes lykke- og lystfølelse. Fordi analysen nedenfor vil reflektere over bøger, der er så små, at de kan bæres tæt på kroppen, sågar direkte mod huden, vil det være relevant også at åbne op for, at den artefaktiske brug ad den vej kan mediere positive sindstilstande. ${ }^{3}$

Den næste teori anfører, at formindskelse aktiverer en imagistisk, kreativ funktion ved enhver genstand, der formindskes. Teorien er især blevet lanceret af Claude LéviStrauss, der i sin bog Den vilde tanke fra 1962 overvejer, hvilken æstetiske funktion der er ved den formindskelse eller nedskallering af verden, der er et kendetegnende element ved de fleste kunstværker. I formindskelsesprocessen indebærer "den grafiske eller plastiske transposition altid ..., at man giver afkald på visse dimensioner ved objektet" (Lévi-Strauss 1994, 34). Visse sanselige dimensioner ved genstanden må opgives; men de tilbageblevne sanselige dimensioner rækker som afsæt for at skabe betydning blandt tilskuerne eller brugerne i mødet med en kunstnerisk miniaturemodel af verden. For at forklare illusionen af helhed i kunsten anfører Lévi-Strauss: "I modsætning til det, der sker, når vi forsøger at erkende en ting eller et væsen i virkelig størrelse, så går erkendelsen af helheden forud for erkendelsen af delene, når det drejer sig om en skalamodel" (ibid.; Lévi-Strauss' kursiv). Den illusoriske helhed afhænger især af beskuerens/brugerens aktive engagement med et udfylde tomrummene efter de opgivne sanselige dimensioner ved genstanden. At udfylde tomrummene og således opretholde illusionen om helhed i kunstværket, fx en formindsket genstand, er et spørgsmål om at erstatte sanselige dimensioner med erkendelsesmæssige, hvilket er en kreativ proces, som ikke længere er i kunstnerens hænder, idet vedkommende har fjernet sig fra genstanden, hvormed processen er overdraget til beskueren eller brugeren. ${ }^{4}$

Jonathan Z. Smith har direkte kommenteret den aktive rolle, som religiøse mennesker kan opnå, når de får adgang til at håndtere religiøse genstande, herunder helligtekster. I sin artikel "Trading Places" fra 1995 argumenterer Smith for, at der i senantikken skete et skred i forhold til, hvor ritualer gennemførtes. Stedet for ritualers gennemførelse syntes at skifte fra det arkaiske tempel til de private hjem (Smith 1995, 21). Som del af dette skifte begyndte formindskede og bærbare genstande så som altre,

3 Se Schleicher 2017 for en mere detaljeret indføring i min skelnen og til betydningen af sanseintegration ved artefaktisk brug.

4 Susan Stewart når en lignende konklusion i sit æstetiske og semiotiske studie af formindskelse og forstørrelse. Hun kombinerer det dog med tanker om begær og kontrol i lighed med Dehouves og Gores konklusioner, der vil blive gennemgået nedenfor (Se fx Stewart 1993, 37-69). Stewart anvender Lévi-Strauss' forståelse direkte på side 48. 
statuetter, amuletter og bederemme at supplere ritualiseringer af fortællinger og diskurser på en måde, der muliggjorde, at ritualers forankring i det arkaiske tempel blev erstattet med en forankring i hjemmet (Smith 1995, 24-25). Smith identificerer religiøse genstandes flytning, formindskelse og bærbarhed inklusiv adgang til religiøse narrativer og diskurser som afgørende for udviklingen i senantikken af individuel religiøs agens, idet disse faktorer muliggjorde et brud med præsters monopol herpå. ${ }^{5}$

I tråd med Smiths opfattelse argumenterer Danièle Dehouve for, at kultgenstande blev løsnet fra en første kontekst og gjort bærbare på en måde, der muliggjorde individuel håndtering. Dehouve bidrager til de teoretiske refleksioner over, hvad der sker, når en rituel genstands dimensioner modificeres, med tre forståelsesudkast. For det første kan formindskelse være en måde at strukturere verden på (Dehouve 2016, 509). ${ }^{6}$ For det andet muliggør formindskelse, at en genstand kommer inden for alle de menneskelige sansers rækkevidde (Dehouve 2016, 512). For det tredje indebærer formindskelse en gentagelig proces og dermed en duplikation af et eller flere motiver ved genstanden om end i en anden målestok, der faciliterer dynamik og nyskabelse (Dehouve 2016, 524).

Dehouves forståelsesudkast fortjener udfoldelse. Jeg vil begynde med hendes sidste antagelse af, at dublikation i ny målestok indebærer nyskabelse gennem gentagelse, hvormed hun understreger, at resultatet - det være sig en kopi eller en efterligning - aldrig er identisk med sit forlæg. Den nye tids- og stedmæssige kontekst for det duplikerede vil uundgåeligt indebære en ny fortolkningssituation, der vil ændre på receptionen af det duplikerede, på samme måde som gentagelsesprocessen altid indebærer muligeden for en intenderet eller tilfældig variation af forlægget, hvilket medfører nyskabelser. For at beskrive gentagelsesaspektet ved formindskelse vil jeg inddrage Ian Readers analyse af formindskede pilgrimsruter i Japan, der er blevet nedskaleret fra et omfattende pilgrimsruteforlæg så som ruten med de 88 pilgrimsmål på øen Shikoku.

Mangel på tid, fysisk overskud og økonomi forhindrede mange buddhister i at rejse til Shikoku på en 1500 kilometer lang pilgrimsvandring sammen med den engang historiske, men senere imaginære Kobo Daishi (774-835) på dennes fødeø Shi-

5 Smiths forståelse af formindskelse som drivkraft for religions udvikling i senantikken anvendes og underbygges af Moyer og Dieleman, der argumenterer for, at elementer fra ægyptisk tempelreligion blev overført til kultstatuetter en miniature, der egnede sig til brug blandt omvandrende helligmænd eller i hjemlig praksis i sidste del af græsk-romersk periode i Ægypten (Moyer and Dieleman 2003, 49, 67-69).

6 Dehouves præliminære formindskelsestypologi udmærker sig ved at være rig på empiriske detaljer fra mellemamerikanske rituelle kontekster. Jeg forstår dog ikke, hvorfor hun vælger at anvende Blumenberg til at reflektere over strukturering, når hun kunne have kontekstualiseret sin egen brug af Lévi-Strauss (Dehouve 2016, 505) ved at referere til Lévi-Strauss' forståelse af formindskelse i kunsten som en kombination af bricoleurens og ingeniørens ambitioner. Hvor bricoleuren ifølge LéviStrauss skaber strukturer ved hjælp af det forhåndenværende og tilfældige begivenheder, skaber ingeniøren tilfældige begivenheder ved hjælp af struktur. Ifølge ham befinder den kunstneriske skabelsesproces sig midt imellem, men også som et forsøg på at ordne verden. Bricolage, kunst og videnskab er alle midler til at indstifte en eller anden form for orden i universet (Lévi-Strauss 1962, 910. $22 ; 30)$. 
koku. Som et alternativ blev miniatureudgaver af ruten med de 88 pilgrimsmål etableret rundt om i Japan fra $1691 \mathrm{og}$ frem. Denne mangedobling af pilgrimsruter indebar nye egenartede rituelle praksisformer med dobbeltreference til Shikoku-ruten og miniaturerutens umiddelbare kontekst, hvormed mennesker fra forskellige regioner blev sat i kontakt med templer og steder, der havde dybe rødder i japansk historie (Reader 1988, 53). Samtidig muliggjorde den lokale tilegnelse af et imponerende ritual en protest mod Shikokus forrang som mål for pilgrimsfærd, hvormed der opstod dynamiske forandringer i regionale selvforståelser og magtrelationer (Reader 1988, 5556). På denne måde argumenterer både Dehouve og Reader for, at det kreative potentiale, der opstår i formindskelsesprocesser, udspringer af den uundgåelige variation, som gentageligheden ved formindskelse indebærer.

Dehouve skelner i præsentationen af sine forståelsesudkast mellem det, at formindskelse forlener struktur til verden, og det, at formindskelse placerer en genstand inden for rækkevidde af menneskets sanser (Dehouve 2016, 509, 512). Hun anser således strukturering og placering som to distinkte aspekter ved formindskelse, men jeg vil argumentere for, at de er forbundne. Mit argument bygger på Steven J. Gores' studie af miniatureportrætter i 1700-tallets England, hvor han bemærker, at det at sanse miniatureportrætter medierer et indtryk - nogle gange reelt, nogle gange illosorisk - af at knytte an til, eje og kunne håndtere dem. (Gores 1997, 592 n12). På lignende vis kan en formindsket bog mediere et reelt eller illusorisk indtryk af, at hele bogens indhold kan holdes i hånden, kan være ved hånden og kan håndteres.

Brug af miniatureportrætter i 1700-tallets England illustrerer, hvordan medlemmer af middelklassen nu havde råd til at bestille miniatureportrætter og dermed have adgang både til repræsentation af en fraværende anden og demonstrere loyalitet over for denne anden (Gores 1997, 574). Normalt bar man miniatureportrætter under tøjet, tæt på kroppen, for på subtil vis gennem kropskontakt at markere en følelsesmæssig, sågar intim tilknytning til en person. Hertil kommer ifølge Gores, at formindskelse af den fraværende person til en bærbar genstand er et spørgsmål om at forvandle den portrætterede til noget, der kan håndteres og ejes. Der kan være tale om en form for tæmning af den begærede, der forlener miniatureportrætholderen med en følelse af sikkerhed og forsikring om, at hans eller hendes hengivenhed gengældes af den portrætterede elskede (Gores 1997, 576). Retten til sådan en forsikring hidrører muligvis fra det forhold, at lidenhed i kombination med miniaturegenstandens materialitet tillod en overskuelig udgift til udsmykning som en form for investering i de elskendes følelsesmæssige forbindelse (Gores 1997, 577). Med en sådan manipulering af miniatureportrættet foreslår Gores, at den hyppige forekomst af monogrammer og hårlokker, der indarbejdedes i miniatureportrættet og dets omslag, forvandlede genstanden fra en metaforisk repræsentation af den elskede til en metonymisk. Det rubricerer miniatureportrættet som en slags talisman, der nedkalder den fraværendes tilstedeværelse i den manipulerbare genstand (Gores 1997, 577); eller sagt med Lévi-Strauss' ord, så opretholdes illusionen om helhed i kombination med illusionen om kontrol.

I min analyse nedenfor vil jeg argumentere for, at sådanne investeringer er vigtige, hvad angår miniaturebøger i jødisk religion, fordi bøger, der tænkes at rumme guddommelige ord eller inkludere referencer til guddommen, oftere synes at være blevet 
udsmykket end sekulære bøger, hvilket indikerer et ønske om at investere i eller endda manipulere den eftertragtede, intime relation med det guddommelige. Jeg vil også trække på Gores' observation, at øget mulighed for sansning har relevans for alle formindskede genstande, idet lidenhed gør det muligt at opbevare genstande tæt til kroppen på måder, der aktiverer en sansebaseret, ofte positiv respons, som jeg i forbindelse med artefaktisk helligtekstbrug selv har argumenteret for.

\section{Analyse af formindskede bøger i jødisk religion}

\section{Menighedsregler}

Verdens ældste, ekstante pergamentruller såvel som de første jødiske miniaturebøger er eksemplarer af Sekthåndbogen (1/4QS), der indgår i de såkaldte Dødehavsruller. Sekthåndbogen beskriver daglig praksis og ritualer såvel som optagelsesregler for nye medlemmer af en sekt, der fra det andet til det første århundrede f.v.t. søgte frelse gennem en pietistisk levevis, baseret på en dualistisk ontologi. Manuskripterne 4QSi og 4QS-f, som de kaldes, er skrevet ikke på papyrus, men på pergament og udgør verdens ældste ekstante pergamentruller. Eftersom de måler henholdsvis 4,4 og 7,6 centimeter i højden, udgør de også de ældste ekstante miniaturebøger i jødedommen. To førende eksperter, hvad angår viden om Dødehavsrullerne, Philip S. Alexander and Geza Vermes, gætter på, at manuskripterne sandsynligvis er eksempler på miniatureruller, der var blevet fremstillet med det formål at skulle kunne bæres rundt på af et sektmedlem, måske en opsynsmand eller lærer (Alexander and Vermes 1998, 5). Med andre ord havde sektmedlemmerne nok formindsket disse menighedsregler for at muliggøre bærbarhed, fordi det tekstlige indhold blev vurderet så betydningsfuldt for frelsen, at uhindret tilgængelighed blev betragtet som en nødvendighed uanset, hvor sektmedlemmet befandt sig.

\section{Bønnebøger}

Den ældste, ekstante bønnebog stammer fra ca. 840, er skrevet i kodeksformat og måler 10 x 7,5 centimeter (Woollaston 2013). Fra det 9. århundrede og frem blev den jødiske bønnebog føjet til jødiske familiers private bogsamlinger. Bønnebogen indeholdt primært bønner, af hvilke de fleste var hele eller delvise gengivelser af de bibelske salmer. Tobias Foa udgav den første trykte jødiske bønnebog i 1555, der målte 7 x 4,5 centimeter. På bønnebogens første side bragte Foa sine bemærkninger om, at bønnebogen var tiltænkt anvendelse både i hjemmene og for dem, der var på farten. Europæiske jøder havde ofte beskæftigelse inden for handel, hvor de nød godt af deres forbindelser med slægtninge, der var blevet spredt langs jødiske migrationsruter så langt væk som til Kina. Disse handelsmænd havde undervejs mellem jødiske hjem 
brug for et eksternt hukommelseslager ${ }^{7}$ for ikke at glemme faste- og højtidsdage i løbet af det jødiske år. Af den grund var Foas bønnebog udstyret med en liturgisk kalender til sidst, hvilket kom til at danne præcedens for mange følgende bønnebøger. Nogle udgaver indeholdt de ugentlige torah- og profetafsnit, ligesom bibeltekststederne, der læstes ved jødiske højtider, også blev bragt. I mangel på nærvedliggende jødiske menigheder med rituelt gyldige torahruller blev en sådan sammensat bønnebog den jødiske vade mecum og af den grund også med tiden den hyppigst formindskede jødiske bog (Feffer 1969, 38). Bønnebogen gjorde det muligt for lægjøder at udføre de fleste ritualer, individualiseret som de nødvendigvis måtte blive, og gav dem således adgang til en profan kodeksversion af nogle af Guds ord. Samtidigt, fordi bønnebogen typisk ville være den eneste bog, som en rejsende jøde havde med sig, indeholdt den med tiden også sekulær information om fx afgangstider for færger og diligencer samt vejkort og valutakurser for relevante lande (Rivkin 1939, 208; Feffer 1969, 39). Den jødiske bønnebogs popularitet understøtter Smiths observation af religionshistoriens udvikling i retning af individualiserede ritualer takket være formindskelser, ligesom det bekræfter skriftlighedens basale funktion, nemlig at fungere som eksternt lager for information.

Den religionshistoriske udvikling i retning af individers øgede religiøse agens hænger nøje sammen med ændringer i medialisering, især de tekniske muligheder for en forholdsvis ubesværet distribution af bønnebøger, hvilket bekræftes af udgivelser, der retter sig mod kvinder, unge og børn som læsere/brugere. En bønnebog, kendt som Meah Berachot (egl. 'de hundrede velsignelser'), på 4 x 3,6 cm stammer fra det 18. århundrede. Den indeholder tre velsignelser, der har relevans for det at bage brød, tage et rituelt bad efter menstruation og tænde sabbatslys, som regnes som bindende påbud for jødiske kvinder. Disse velsignelser står side om side med de traditionelle bønner og bønner for vejfarende, for mennesker i tordenvej og for mennesker, der skal iføre sig nyt tøj for første gang (Facsimile Editions 2017). Denne bønnebog adskiller sig endvidere ved at være håndskrevet på pergament af en professional sofer, dvs. en skriver med kendskab til de formelle krav til produktion af helligtekster. Bogen indeholder en illumineret titelside og 29 miniaturefriser, der illustrerer handlinger med relevans for det, som velsignelserne vedrører. Endelig er der et smuk læderomslag/etui, der beskytter indholdet. I tråd med Gores' konklusioner antyder investeringerne i denne udgave af Mea Berachot, hvad angår materielle omkostninger, tidskrævende produktion, og indholdet af de tre bønner, der vedrører kvinders liv, at bønnebogen er blevet fremstillet med det formål at skulle knytte eller forstærke bånd til en kvinde, måske en vordende brud. Hvad angår ungdommen, besluttede forlægger Meir Crescas fra Amsterdam at værne om den korrekte udtale af bønnerne blandt især unge mennesker, hvorfor han i 1739 udgav en let læselig og håndterbar miniaturebønnebog på 6 x 4,1 cm med vokaltegn (Feffer 1969, 39; se også Kedem Auction House n.d.a). På den lille tunesiske middelhavsø, Djerba, blev en anden bønnebog fremstillet i 1946, der indeholdt en børneudgave af den jødiske bordbøn, således at små børn kunne hjælpes til at udtrykke religiøs andægtighed (eBay 2017a).

\footnotetext{
${ }^{7}$ Se fodnote 2.
} 
I takt med immigrationen til Syd- og Nordamerika steg salget af miniaturebønnebøger. I Fürth i Tyskland blev den første ud af fire 8-centimetersudgaver trykt. Titelsiden specificerer, at denne bønnebog er for rejsende, der skal krydse Atlanterhavet til Amerika. ${ }^{8}$ I andre miniaturebønnebøger fra denne periode skrev kendte digtere fra midten af det 19. århundrede og frem nye bønner til dem, der skulle rejse med skib eller tog, hvilket siger noget om sårbarheden ved en sådan fysisk overgangsfase i ejernes liv, ligesom det også antyder, at bønnebøger kan have haft den amuletlignende funktion at skulle afværge farer på rejsen.

Værnepligt for jøder i både fredstid og i krig foranledigede også udgivelser af miniaturebønnebøger. Bøhmiske rabbinere gav miniaturebønnebøger til jødiske soldater, når de blev indrulleret i den dengang østrigske hær fra midten af det 19. århundrede og frem til Første Verdenskrig (Rivkin 1939, 211n). Jøder, der lod sig hverve til de allierede styrker under Anden Verdenskrig, blev også udstyret med jødiske bønnebøger for at sikre Guds nærvær og beskyttende kraft. I dag udgiver hære stadig jødiske bønnebøger. I 2006 lod den amerikanske hær udgive en økumenisk jødisk bønnebog for de forskellige jødiske retninger i USA. I Israel tildeler den israelske hær sine soldater en hebræisk bibel og et komplet bedeudstyr inklusiv en miniaturebønnebog (eBay 2017b). Til sammenligning har de britiske bevæbnede styrker taget det digitale format til sig og stiller kun forskellige religioners bønnebøger til deres soldaters rådighed online som PDF-filer (Her Majesty's Armed Forces 2006).

\section{Salmer}

Salmernes Bog hører til Skrifterne i den hebræiske bibel med kun en ringe grad af hellighed sammenholdt med Torah, dvs. Mosebøgerne. Alligevel har Salmernes Bog gennem århundreder været den mest skattede del af den hebræiske bibel og har altid været den mest oplagte kandidat til at fungere som en form for amulet, der skulle afværge ondskab, eller som en form for talisman, der skulle tiltrække sig Guds kraft, held og medgang (Schleicher 2009, 56-58). Ifølge Talmud (bGit 35a) blev nygifte par i senantikken givet håndskrevne udgaver af Salmernes Bog på hebræisk blandt andet for at sikre, at parret fik del i den kommende verden og for at afværge dæmonangreb og diverse andre ulykker. Den ældste, ekstante miniatureudgave af Salmernes Bog stammer fra 1565 og blev trykt af Robert Etienne i Paris. Selv i dag betragter jøder af mystisk observans recitation af alle 150 salmer som en apotropæisk handling, der kan afværge ondskab. Det overrasker derfor ikke, at udgaver af Salmernes Bog er blevet formindsket i sådan grad, at deres fremtoning og funktion er mere amulet- eller talismanagtig end bogagtig. Min påstand understøttes af en ny opfindelse inden for judaica-smykker, nemlig en USB-nøgle, som man eksempelvis kan få i en forsølvet udgave

8 Indtil man fik kendskab til Fürth-udgaven fra 1842 var historikere af den overbevisning, at immigrationen til den nye verden fra Tyskland først begyndte efter revolutionerne i 1848-1849, hvor liberale og arbejderklassen gjorde oprør mod det tyske aristokrati. Selve titelsiden og de betragtelige omkostninger ved at sætte dette tryk gav imidlertid anledning til historikernes korrektion af de hidtidige antagelser og pegede i stedet på, at immigrationen begyndte forud for de tyske revolutioner (Rivkin 1939, 210-211). 
med en indlagt ædelsten som vedhæn til en halskæde (World of Judaica 2017). Her har bogens artefaktiske egenskaber fået overtaget, omend det digitale format stadig tillader selve tekstens bærbarhed og hermeneutiske brug, dog kun hvis USB-nøglen indsættes i en computer eller anden form for elektronisk enhed.

\section{Haggadah shel Pesach}

Pesach, også kendt som den jødiske påske, er en af jødedommen vigtigste højtider. Den bog, hvormed man ihukommer udfrielsen fra Ægypten, er ikke Exodus i den hebræiske bibel, men haggadah shel pesach (egl. 'påskefortællingen'). Den første haggadah shel pesach blev sandsynligvis forfattet i det 13. århundrede og udgør en ritualmanual for den første aften i påskedagene, der fejres på særlig vis i jødiske hjem. Den lægfolkelige fejring i hjemmet indebærer alle tilstedeværendes aktive deltagelse, hvilket indbefatter, at man læser, tænker med, stiller spørgsmål, spiser symbolske retter og åbner hoveddøren i håb om, at Elias står der for at varsle Messias' komme. Når påske-aggadahen ikke lige er i hænderne på de tilstedeværende ved påskebordet, vil den sandsynligvis ligge i deres skød eller ved siden af tallerkenen inden for rækkevidde, så snart recitation af påske-aggadahen genoptages, idet alle er forpligtede til at følge med i recitationen. Med andre ord forklarer behovet for let tilgængelighed og orienterbarhed i teksten, hvorfor især påske-aggadahen ofte er blev formindsket. Faktisk nævner Jonathan Z. Smith selv, hvordan påskeritualet flyttes til hjemmet som støtte for sin teori om, at formindskelse sammen med narrativisering muliggjorde ritualer i hjemmene og dermed individers øgede religiøse agens (Smith 1995, 22). Påske-aggadahen citerer fra Torah, trækker på specifikationer fra Mishnah og indeholder ofte illustrationer. Et af de tidligste og smukkeste eksempler er den gyldne påskeaggadah fra Barcelona fra 1320 med dens 56 miniaturefriser (The British Library n.d.). Mens den gyldne påske-aggadah i sig selv ikke er en miniaturebog, er dens illuminerede friser det. Disse friser bevidner i tråd med Lévi-Strauss' forståelse kunstnerens imagistiske forsøg på at udfylde diverse fortællemæssige og begrebsmæssige lakuner, som opstår i selve haggadah-teksten som følge af formindskelsen af Exodus-beretningen som forlæg. Andre påske-aggadaher foreligger en miniature så som skriveren Meshullam Zimmel ben Moshe fra Polnas påske-aggadah fra 1721, som måler 9,2 x 6,1 centimeter, og som er fremstillet i Wien på pergament på bestilling af Meir Poesing som gave til hans kone Juetl ifølge dedikationen inde i bogen (The Israel $\mathrm{Mu}$ seum, Jerusalem 2017). I overensstemmelse med Gores' argument vidner det om, hvordan investeringer i små genstande kan repræsentere investeringer i emotionelle bånd.

Let adgang til tekstens indhold er ikke eneste grund til formindskelse. Avraham Haba er en blandt flere kunstnere, der har udfordret kodeksformatet, som har været anvendt til påske-aggadaher, ved at subversere forventninger til format og skriveoverflade. Æg hører med til festmåltidet den første aften i påsken. De skal spises hårdkogt som symbol på de hårde livsvilkår, da israelitterne var slaver i Ægypten. Haba skrev derfor i 1967 hele påske-aggadahen på et 6 centimeters højt æg med mikroskrift 
og kombinerede således to centrale genstande i påskeritualet (Kedem Auction House n.d.b). Ud over den imagistiske funktion ved en sådan mediering vidner ægge-aggadahen også om Habas kunstneriske evner såvel som hans investering i og demonstration af personlige bånd til jødisk kultur og tradition.

\section{Purim Megillot (egl. purim-ruller)}

Under den karnevaleske vinterhøjtid i jødedommen, der kendes som 'purim', skal jøder lytte til oplæsningen af Esters Bog fra rulleformat i synagogen. Enhver jøde, mand som kvinde, skal ifølge Talmud (bMeg 4a) under gudstjenesten se ned og læse med i en egen medbragt rulle, fordi det er et krav, at man skal forstå ethvert ord i hele fortællingen. I den forbindelse har det været en fordel, at Ester-rullen blev produceret så lille, gerne helt ned i miniatureformat, så den blev let bærbar og håndterbar. At eje sin egen Ester-rulle bliver her kutyme, der samtidig muliggør et element af individuel agens for begge køn - i dette tilfælde ikke i hjemmet, men i en liturgisk kontekst. Det var og er fortsat typisk, at Ester-ruller skrives smukt i hånden af en sofer, fx på bestilling af en bruds forældre med henblik på at give en Ester-rulle til brudgommen ved selve bryllupsfesten. I Gores' perspektiv anvendes smukt udførte miniatureruller i sådanne tilfælde til at investere i personlige relationer også til mænd.

I Mellemøsten og Indien blev formindskede Ester-ruller ikke dekoreret; men deres omslag eller hylstre var ofte fremstillet i ædelmetaller eller lignende værdifuldt materiale. I den askenasiske region, dvs. i det område, hvor jøder talte en germansk dialekt med hinanden, kunne skriverne vælge at indarbejde illuminationer. Ester-ruller fra det sefardiske område, dvs. dér, hvor jøder talte en spansk dialekt med hinanden, ville man følge muslimsk praksis med kun at dekorere Ester-ruller med florale eller geometriske motiver (Feffer 1969, 35-36). I tråd med Readers observation af, at miniatureportrætter muliggør en variation i udførelsen med henblik på at markere en lokal afstandtagen til et autoritativt forlæg, signalerer formindskede Ester-ruller, der tilmed følger lokale udsmykningstraditioner, den kulturelle region, som køber hører til.

\section{Hebræiske bibler og udgaver af Mosebøgerne}

John Clein fra Leiden udgav den første hebræiske miniaturebibel i et kodeksformat på 9,9 x 6,8 cm i 1529 (Welsh 1987, 63). I takt med den teknologiske udvikling blev hebræiske miniaturebibler til tider trykt med så små bogstaver, at selve teksten blev ulæselig. Sådanne ulæselige bibler refererer man til som abiblia, og de sælges ofte med et tilhørende forstørrelsesglas (fx PBS 2008; Welsh 1987, 7). Generelt havde komplette hebræiske bibler ingen liturgisk funktion, men anvendtes i stedet som central studietekst og identitetsmarkør i jødiske hjem og religiøse institutioner så som skoler med basal hebræiskundervisning og rabbinske akademier. På disse institutioner var forholdsvis store, læselige versioner at foretrække. Hvis en hebræisk bibel derfor blev 
formindsket, tyder meget på en kontekst, hvor et menneske var rejsende, skulle skjule sit religiøse tilhørsforhold og/eller skulle emigrere. ${ }^{9}$

Torah, dvs. Mosebøgerne, i kodeksformat benævnes humash eller hamishah humshey torah. Kantorer benytter en humash for at lære vokallydene, der knytter sig til den konsonantiske torahtekst i rulleformat, således at de kan forestå recitationen af Torah under gudstjeneste med den korrekte udtale. For at en torahrulle skal være liturgisk gyldig, er det et krav, at vokaltegn er udeladt. Trykning af formindskede humasher kendes fra 1540 (Morse-Harding 2015), hvilket har været befordrende for kantorers og lægjøders forberedelser, når de under gudstjeneste kaldtes op for at læse op fra torah. I den forstand eksemplificerer en humash i særlig grad, hvordan bøgers basale funktion er at tjene som eksternt hukommelseslager. Hertil kommer, at formindskede torahudgaver i kodeksformat også muliggjorde tæt kontakt til Guds egne ord, hvis man skulle rejse, skjule sit religiøse tilhørsforhold eller emigrere, om end helligheden delvist forsvandt pga. det liturgisk ugyldige ved humashens format, materiale og produktionsproces.

Den mest koncentrerede manifestation af hellighed ligger i rulleformatet, når det anvendes på den hebræiske bibels første del, dvs. Torah, der rummer Guds lære, som den formidles til Moses. I protoaksial tid ${ }^{10}$ foranstaltede præster og levitter oplæsning af Torah til folket (Neh 8,8); men i århundrederne umiddelbart inden vor tidsregnings begyndelse undslap Torah specialisternes kontrol og blev distribueret i forskellige, til tider varierende håndskrevne versioner blandt lægfolk i takt med, at læsekundskab udbredtes.

Fra og med det andet århundrede f.v.t. findes der belæg for den praksis, at et specifikt udvalg af passager fra Torah, samlet kendt som shema, reciteres morgen og aften. Tekstpassagerne blev skrevet med mikroskrift på pergament, placeret i små hylstre, kendt som mezuzot, der så blev hæftet på dørstolperne i jødiske hjem, og i æskerne på jødiske bederemme (tefillin), der placeres på panden og venstre overarm, tættest ved hjertet, for at signalere et mentalt fokus og oprigtighed i recitationen af selvsamme tekststeder. Sådanne tefillin og mezuzot blev fundet under udgravningerne ved Khirbet Qumran, hvilket vidner om en andægtig brug af formindskede tekstfragmenter blandt medlemmerne af den føromtalte sekt bag Dødehavsteksterne. I græskjødiske tekster fra begyndelse af vor tidsregning, refererer Josephus (Antiquities IV, $8,13)$ og Mattæus $(23,5)$ til bederemme og dertilhørende æsker med det græske ord

9 Det skal nævnes, at dette behov for at formindske bibler og andre religiøse tekster så meget, at de kunne skjules, har gjort sig gældende i andre religioner end blot den jødiske. Fx måtte franske huguenotter og andre tilhængere af den protestantiske reformation i det 16.-17. århundrede skjule deres fransk- eller tysksprogede bibler. De blev derfor fremstillet en miniature og blev senere kendt som 'bibles de chignon' og 'Haahrknotenbibel', der i begge tilfælde betyder 'hårknoldsbibler', idet de kvindelige tilhængere kunne skjule disse bibler under deres knold i nakken. For mere, se www.museeprotestant.org: "Objets de la clandestinité, og www.bibelausstellung.de: "Haarknotenbibel" (begge set den 14. april 2020).

10 'Protoaksial tid' refererer til den tidligste fase i overgangen fra arkaisk kultur, kendetegnet ved især bystatskultur og velsignelsesreligion under specialisters ledelse, til aksial kultur, kendetegnet ved især imperiekultur og frelsesreligion ved individers egen asketiske bestræbelse. For mere herom, se Bellah 1964. 
phylaktēria, der betyder amuletter. Selve det græske ord og den metonymiske overførsel af Guds nærvær gennem de guddommelige ord, der indsættes i tefillin og mezuzot, understøtter både Dehouves og Gores' argumenter om formindskelsers metonymiserende og manipulationsmæssige funktioner. ${ }^{11}$

I år 70 e.v.t. brændte romerne templet i Jerusalem ned til grunden. At Torah sikrede en mobilitet og tilgængelighed af Guds nærvær, fremdrages ofte som forklaring på, hvordan den tempelløse jødedom som religion kunne overleve den nationale katastrofe og det eksil, der fulgte. Omkring 600 e.v.t. foreskriver den babylonske talmud, at enhver mand selv skal skrive en torahrulle, og hvis han ikke var i stand til det, skulle han få én fremstillet (bSan 21b; bMeg 27a). Dette påbud sikrede i tillæg til fraværet af et kultisk centrum en distribution af torahruller, et fokus på en hjemlig eller mindre social kontekst og individuel religiøs agens.

Kun pergamentruller skrevet på skind fra dyr, der var kosher, dvs. tilladte, at spise (bMeg 19a, bShab 79b), skrevet på originalsprog med det assyriske alfabet og med blæk (mYad 4:5) var egnet til liturgisk brug. ${ }^{12}$ Med andre ord insisterede de tidlige rabbinere på rulleformatet, hvilket kan have sin forklaring i den gensidige dis-identifikation mellem rabbinskorienterede jøder og Jesus-følgende jøder. Sidstnævnte gruppe, som senere konsoliderede sig som kristne, foretrak nemlig kodeksformatet. Torahs rulleformat besværliggør en let orientering i teksten. Til gengæld signalerer det jødernes særstilling som modtagere af Sefer haTorah, dvs. torahrullen. Gud befalede Moses at skrive en rulle, hvorpå Moses befalede levitterne at placere den ved siden af de to stentavler som uddybende vejledning til, hvordan man bør leve (Deut 31,24-27). Sefer, der betyder 'bog' uanset format, er på hebræisk afledt af roden s-p-r, der betyder 'at fortælle', hvilket understreger, at rulleformatet trods alt tilbød et bedre medium for fortælling end tavler. I rivaliseringen med Jesus-bevægelsens jøder valgte rabbinerne ikke at autorisere kodeksformatet for deres mest hellige tekst til rituel brug. I stedet foreskrev rabbinerne en investering i rullens artefaktiske aspekter for at signalere loyalitet over for pagten mellem Moses og Gud som et middel til at påstå deres forrang og adgang til en metonymisk repræsentation af Gud trods eksil og rivaliseringssituationen.

I løbet af historien har mange jødiske lægfolk og mystikere betragtet enhver liturgisk gangbar torahrulle som en mediator mellem den praktiserende jøde og Gud, der kunne forlene én med velsignelse i form af frugtbarhed, beskyttelse og godt helbred. Et kendt eksempel på en amuletisk og talismanisk rulle i et lille format er Zghair Derna, der betyder 'den lille fra Djerna'. Den tilhører den jødiske menighed i Derna, der i dag ligger i Libyen. Rullens lidenhed har tiltrukket sig legender om, hvordan

11 Det støtter endvidere Heather Coffeys udlægning af formindskede koraner, når hun skriver, at alle små manuskripter har et amuletlignende potentiale, der understøtter fromhed, idet det formidler brugerens adgang til noget numinøst qua brug tæt på kroppen (Coffey 2009, 103).

12 For mere om torahrullers artefaktiske kendetegn, se fx Schleicher 2010, 13-17; Sabar 2009, 139-142. 152. 159. 
den adræt kan bevæge sig og intervenere for at sikre velsignelser og afværge ondskab. Her er det værd at bemærke, hvordan dens påståede adræthed er en intensiveret repræsentation af enhver formindsket torahrulles mobilitet. ${ }^{13}$

Kun et fåtal af formindskede torahruller ville være kvalificeret som både liturgisk medium og miniaturerulle ifølge moderne vestlige standarter, fordi de havde et decideret praktisk formål: at skulle kunne læses. Vel findes der mange små torahruller, hvor lidenheden har muliggjort, at $\mathrm{fx}$ vandreprædikanter, der florerede i renæssancens Europa, let kunne forestå en skriftudlægning eller gudstjeneste, uanset hvor han var. En mindre torahrulle fra 1750ernes Balkan-område er fx monteret i en kuffert, hvor størrelsen har været afgørende for dens bærbarhed og måske en indikation af, at ejeren meget vel kunne have været vandreprædikant (eBay 2017c).

De liturgisk gangbare miniatureruller er ofte af nyere dato og afspejler professionelle jødiske skriveres elitære ambitioner lig bogtrykkernes ambitioner, hvor de benytter miniatureformatet til at udstille deres evner og formåen. Verdens mindste håndskrevne miniaturetorahrulle, der opfylder alle krav til at være liturgisk gangbar, måler kun 5 centimeter i højden og har fået indbygget et forstørrelsesglas i en rude, der er indlagt i låget på sølvkassen, hvori rullen opbevares, når den ikke er i brug (The Yeshiva World 2014). Denne rulles primære anvendelse er næppe liturgisk, men bevidner nærmere skriverens evner og religiøse tilhørsforhold som artefaktiske aspekter ved rullen.

En rulle, hvis lidenhed var afgørende for dens liturgiske anvendelse, fandt imidlertid anvendelse den 24. oktober 2014, hvor den muliggjorde kvinders religiøse agens foran Grædemuren i Jerusalem. Efter at være blevet nægtet adgang til kvindernes område ved Grædemuren med en stor torahrulle smuglede kvinder fra den feministiske gruppering "Women of the Wall" en miniaturetorahrulle ind på kvindeområdet. Rullens formindskede størrelse muliggjorde, at kvinder for første gang kunne gennemføre en oplæsning fra Torah ved Grædemuren, og at en tolvårig pige ved navn Sasha Lutt kunne læse med under sin bat mitzvah ${ }^{14}$, hvilket var den første af sin slags ved Grædemuren (Ferber 2014). Mens miniaturetorahrullen her var liturgisk gangbar, er det ikke inden for normativ israelsk jødedom, at kvinder læser op fra torahrullen, og slet ikke ved Grædemuren pga. den ultraortodokse orientering i Israels to overrabbinater og dermed de liberale retningers sværere eksistensvilkår i Israel. At rullen var så lille, at den kunne skjules, muliggjorde denne religiøst politiske demonstration for kvinders ret til religiøs agens i menighedssammenhænge. I tråd med LéviStrauss, Dehouve og Reader muliggør lidenheden en variation af et forlæg, herunder protest og konkretisering af et alternativ, ja, et forsøg på at udfylde tomrummene i disse kvinders religiøse liv.

13 For mere om legenden om Zghair Derna, se Sabar 2009, Ben-Amos 2011 og Goldberg 2013.

14 'Bat mitzvah' (egl. datter af buddet) fungerer som en pendant i ligestillingens navn til jødiske drenges 'bar mitzvah' (egl. søn af buddet), der er blevet udbredt i reformjødiske og konservative jødiske kredse i de sidste årtier af det 20. århundrede. Tanken er, at et barn, når det når puberteten, demonstrerer sit kendskab til den jødiske religiøse tradition, herunder sin evne til at læse torah på hebræisk og således sikre, at han/hun også kan bidrage til gennemførelsen af en jødisk gudstjeneste. 
Jeg vil afslutte min redegørelse for formindskede bøger i jødisk religion med en beretning om ikke en decideret miniaturetorahrulle, men dog en lille Torah, der bidrager til en forståelse af formindskelser af religiøse tekster. Rullen er skrevet på rådyrskind, hvilket er meget sjældent, da et rådyrskind kun rækker til én pergamentside, mens det kræver 80 sider at skrive en torahrulle. Dådyrstorahen var blevet fremstillet omkring 1800 i Østeuropa. Beretningens udgangspunkt er Rabbi Yaakov Meir, der havde arvet den fra sin farfar, en omrejsende handelsmand, der havde fået den fremstillet med henblik på at medbringe den, når han var på farten. I stedet for træstokke, som en torahrulle normalt er viklet om, havde rullen kobberstokke med den konsekvens, at rullen tidligt begyndte at afgive rust til siderne, som forhindrede den i at være liturgisk gangbar. Under nazisternes besættelse af Østeuropa blev Rabbi Meir sendt til Auschwitz. Uden anelse om, hvad der ventede ham, skjulte han sin rådyrstorahrulle i en hemmelig lomme, udformet af et eksternt ærme, der var syet ind i hans frakkes ærme. At rullen var uegnet til liturgisk brug, var ham lige meget. Da han ankom til Auschwitz, blev han bedt om at tage sit tøj af. Den jøde, der havde fået til opgave at indsamle de nytilkomnes tøj, fjernede, uden at nogen så det, rullen fra Rabbi Meirs frakke og bragte den over til Rabbi Meirs barak tre dage senere. Alle jøder i lejren delte denne rulle, hvilket eksemplificerer en mere menighedsagtig brug af en formindsket torahrulle, end det er tilfældet med religiøse miniaturebøger i kodeksformat, der oftest anvendes individuelt. I foråret 1945 blev Rabbi Meir sendt på dødsmarchen gennem Tyskland, idet nazisterne ville forhindre de allieredes befrielse af de indsatte i døds- og koncentrationslejrene. Under marchen skød en nazistisk soldat Rabbi Meir, der endnu engang bar sin rulle i frakkeærmet. Stænk af blod blev fordelt på torahafsnittene Tazria og Metzora, dvs. Lev 12-15, hvilket indikerede nylig læsning, idet disse fire kapitler blev læst under de to uger før og efter hans død. Som om det var bestemt af skæbnen, skete det mange år senere i 1970erne, at Rabbi Meirs barnebarn, Yaakov Maor, fandt dådyrstorahrullen i Wien. Her kunne han identificere den takket være familiefortællingerne om rullen, dens kobberstokke, rusten og blodstænkene fra Rabbi Meir på Leviticus-kapitlerne. Yaakov Maor gjorde krav på rullen, hvilket blev accepteret. Han tog den derpå med sig til Israel, hvor han boede og nu kunne returnere den til sin mor, Rabbi Meirs datter. Mor og søn sørgede for, at Rabbi Meirs blod blev skrabet af rullen, hvorpå de kunne begrave det i Jerusalem. Familien bekostede også en ny torahkappe, der blev broderet med et citat fra Numeri om, hvordan pagtens ark blev bragt til det forjættede land; men de kombinerede det med navnene på de byer, som familien med rullen havde bevæget sig igennem, førend de ankom til Israel. Trods rullens defekte liturgiske status fortsatte denne familie med at investere i dens bevarelse, fordi den repræsenterede adskillige bånd til afdøde og levende familiemedlemmer, til deres fortidige og nutidige opholdssteder såvel som til de grusomheder, som ramte dem og det øvrige jødiske folk, og som nogle af dem overlevede. Havde rådyrstorahrullen ikke været så lille, ville den ikke kunne have været en kilde til hukommelse og betydningsskabelse i både individuel og kollektiv sammenhæng i Auschwitz. Den ville ikke kunne have fungeret som 'hub' for familiefortællinger, gennemrejste territorier, smerte og glæde (Rizel 2016). 


\section{Konklusion}

I min analyse af formindskede bøger i jødisk religion har jeg konstateret, at alle eksempler på formindskede bøger i en eller anden udstrækning har demonstreret bøgers basale funktion, nemlig at tjene som eksternt hukommelseslager, der medierer adgang til religiøse fortællingers kanoniske ordlyd og information om, hvordan handlinger skal udføres som middel til at opretholde og signalere brugerens jødiskhed.

De formindskede menighedsregler, hebræiske bibler og Mosebøger i kodeksformat og som torahruller antyder, at formindskelse af størrelsen muliggør let adgang til, hvad brugerne opfatter som guddommeligt inspirerede tekster og deres metonymiske repræsentation af Gud, primært blandt lægfolk. Bøgernes bærbarhed som følge af formindskelse forklarer endvidere, hvorfor formindskede udgaver har nydt udbredelse særligt under eksil og forfølgelse af både lægjøder og omvandrende specialister.

Jonathan Z. Smiths teoretiske refleksioner inspirerede mig til at tænke formindskelse som en proces, der over tid har faciliteret individualiseret religiøsitet. Hans tese har jeg kunnet finde belæg for i brugen af bønnebøger og små påske-aggadaher til brug for alle deltagere uanset køn og alder under påskemåltidet, i mænds og kvinders læsning fra egne Ester-ruller under Purim-højtidens synagogegudstjeneste, i bibel- og torahkodekser, der har muliggjort private studier og læseforberedelser, og endelig i kvinders torahoplæsning i en liturgisk sammenhæng, hvor sådanne oplæsninger ellers har været forbeholdt mænd.

Mens alle håndskrevne eksempler på formindskede religiøse tekster demonstrerer skriverens evner og formåen, har særligt udfærdigelsen af de få eksisterende miniaturetorahruller foranlediget skriverens mulighed for at markere hans, og senest også hendes religiøse tilhørsforhold. ${ }^{15}$ Markering af tilhørsforhold kan meget vel være et overset artefaktisk aspekt ved formindskede udgivelser også blandt kristne trykkere, hvilket understøttes af det faktum, at mange af de tidligste trykkere, herunder Gutenberg, prioriterede trykning af bibler.

Gores opfattede formindskelse af portrætter som en proces, der muliggjorde deres brug som amuletter og talismaner pga. miniatureportrættets metonymiske aspekt. Jeg overførte denne tese på formindskede helligtekster i jødisk religion og fandt, at bønnebøger, Salmernes Bog og dele eller hele udgaver af Torah har været brugt til at afværge ondskab, tiltrække sig guddommelig velsignelse, sandsynligvis fordi Guds ord tænkes at udgøre deres hellige og numinøse indhold.

Gentagelsen eller reproduktionen af et større forlæg, som formindskelsen jo repræsenterer, forklarer dens imagistiske funktion at udfylde tomrum og dermed dens dynamiske potentiale til at variere forlægget. Denne idé, der er blevet præsenteret af Lévi-Strauss, Dehouve og Reader, har jeg fundet belæg for i påske-aggadahernes miniaturefriser, der udfylder tomrummene efter de dele af Exodus-beretningen, der er

15 Den første kvindelige sofer, Jen Taylor Friedman, blev uddannet i 2007. Se fx hendes færdiggørelse af, hvad der synes at være den første torahrulle skrevet af en kvinde i en rekonstruktionistisk menighed (Friedman n.d.). 
blevet udeladt. Jeg fandt ligeledes belæg herfor i de regionale forskelle på udsmykningstraditioner for formindskede Ester-ruller og $\mathrm{i}$ "Women of the Wall"'s protest imod den patriarkalske liturgis autoritative forlæg ved hjælp af en formindsket torahrulle.

Den sidste indsigt, som analysen har bragt, var inspireret af Gores, og påpeger, hvordan udsmykning af formindskede religiøse bøger har været brugt som investering i emotionelle bånd og personlige forbindelser. Både gavegivning og restaureringen af Meir-familiens dådyrstorahrulle illustrerer, hvordan man har investeret i formindskede bøger for at etablere, opretholde og værne om bånd til individer, kollektiver og endda geografiske steder og historiske begivenheder.

Jeg konkluderer derfor, at formindskede bøger i jødisk religion har tjent til og stadig tjener mange forskellige funktioner. Bøgers tidlige funktion som hukommelseslager for især religiøse fortællinger og argumenter vedrører bøgernes tekstlige indhold og inviterer til en hermeneutisk brug. Det empiriske materiale viser imidlertid også, at mediering af tro og praksis op igennem jødisk religionshistorie på trods af eksil og forfølgelse ikke kun afhang af, at religiøse bøgers tekstlige indhold blev lagret, men også af, at bøgerne blev tilstrækkeligt formindskede, således at de kunne håndteres og skjules af individer. At bøgerne kunne håndteres og skjules er vigtige funktioner ved formindskelse, sådan som det allerede er blevet fremhævet i størstedelen af samlernes litteratur. Hvad samlerne imidlertid ikke har forklaret, er de sanse- og associationsskabende effekter, der følger, når bøger er så små, at de kan håndteres af et enkelt menneske og skjules tæt på huden. Under inddragelse af Lévi-Strauss, Dehouve og Gores kunne jeg således med analysen bidrage til at forstå formindskede jødiske bøger som væsentlige medier for jødisk religion og religiøsitet i et boghistorisk og religionshistorisk perspektiv. Centralt står, at bog- og religionshistoriens gradvist intensiverede formindskelse af religiøse bøger har muliggjort, at religiøse individer har fået adgang til en metonymisk repræsentation af Gud. Formindskede religiøse bøger har medieret en individualiseret, mobil religiøs praksis med potentiale for subversion af religionens normative forlæg, ligesom de har muliggjort indplacering og løbende justering af brugerens placering i et netværk af betydningsgivende relationer og tilhørsforhold.

\section{LITTERATURLISTE}

Alexander, Philip S. \& Geza Vermes

1998 Qumran Cave 4, XIX: Serekh ha- Yahad and Two Related Texts. Oxford: Clarendon Press.

Anderson, Sean Eron \& Marc Levoy

2002 "Cuneiform Tablets", IEEE Computer Graphics and Applications 22/6, 82-88. https://doi.org/10.1109/MCG.2002.1046632

Assmann, Jan

2004 Religion und kulturelles Gedachtnis. Zehn Studien [2000], 2. Aufl., München: Beck.

Bellah, Robert N.

1964 "Religious Evolution", American Sociological Review 29/3, 358-374. 
https://doi.org/10.2307/2091480

Ben-Amos, Dan, ed.

2011 Folktales of the Jews - Volume 3: Tales from Arab Lands, Philadelphia: The Jewish Publication Society.

Bondy, Louis W.

1981 Miniature Books: Their History from the Beginnings to the Present Day, London: Sheppard.

British Library

n.d. "Golden Haggadah”, Online Gallery. http://www.bl.uk/onlinegallery/sacredtexts/golden.html

Bromer, Anne C.

1988 "Art for Miniature Art's Sake", Journal of Decorative and Propaganda Arts 7, 88-95.

Coffey, Heather

2009 "Between Amulet and Devotion: Islamic Miniature Books in the Lilly Library", in: Christiane Gruber, ed., The Islamic Manuscript Tradition, Bloomington: Indiana University Press, 78-115. https://doi.org/10.2307/j.ctt2005ssv.8

Dehouve, Danièle

2016 "A Play on Dimensions: Miniaturization and Fractals in Mesoamerican Ritual”, Journal of Anthropological Research, 504-529. https://doi.org/10.1086/689297

eBay

2017a “1946 Djerba Tunisia MINIATURE SHABBAT PRAYER BOOK Antique/Judaica/Jewish/Hebrew". http://www.ebay.ca/itm/1946-Djerba-Tunisia-MINIATURE-SHABBAT-PRAYER-BOOKAntique-Judaica-Jewish-Hebrew/390779900010?hash=item5afc4c106a:g:IIkAAOxydlFS LSD

2017b “LOT IDF Judaica Tefillin Bag Antique Tfilin Teffilin JEWISH Phylacteries Rare". http://www.ebay.ca/itm/LOT-IDF-Judaica-Tefillin-Bag-Antique-Tfilin-Teffilin-JEWISHPhylacteries-Rare-/202015933502?hash=item2f0916843e:g:zz0AAOSwrqlZiDO6

2017c “Miniature Travelling Torah Scroll Parchment Wimpel Wooden Case Tik Balkan Ca1750". http://www.ebay.com/itm/Miniature-Travelling-Torah-Scroll-Parchment-Wimpel-WoodenCase-Tik-Balkan- Ca1750-/371248960666

Edgren, James Sören

2013 "The History of the Book in China", in: Michael F. Suarez, S. J. and H. R. Woudhuysen, eds., The Book: A Global History, Oxford: Oxford University Press, 573-592.

Edison, Julian I.

1967 "World's Oldest Printing on Paper", Miniature Book News 8, 1-2.

Facsimile Editions

2017 “Me'ah Berachot". http://www.facsimile-editions.com/en/mb

Feffer, Solomon

1969 "Hebrew Miniature Books", Jewish Book Annual 27, 35-41.

Ferber, Alona

2014 "Defying Regulations, Women of the Wall Sneak Tiny Torah Scroll into the Kotel", Hareetz,

October 24. http://www.haaretz.com/israel-news/1.622560

Friedman, Jen Taylor

N.d. "Milestones". www.hasoferet.com

Goldberg, Harvey E.

2013 "The Ethnographic Challenge of Masorti Religiosity Among Israeli Jews", Ethnologie Française 43/4, 583-590. https://doi.org/10.3917/ethn.134.0583

Gores, Steven J.

1997 "The Miniature as Reduction and Talisman in Fielding's Amelia", Studies in English Literature 1500-1900 37/3, 573-593. https://doi.org/10.2307/451050

Her Majesty's Armed Forces

2006 "Armed Forces Operational Service and Prayer Book", London: Ministry of Defense. 
http://health.nzdf.mil.nz/assets/Uploads/JSP587-BritishArmedForces-Prayer-Book.pdf

Hunter, Dard

1943 Papermaking: The History and Technique of an Ancient Craft, New York: Dover.

The Israel Museum Jerusalem

2017 "Miniature Passover Haggadah".

http://museum.imj.org.il/imagine/collections/item.asp?itemNum=354497

Kallendorf, Craig

2013 "The Ancient Book", in Michael F. Suarez, S.J. \& H.R. Woudhuysen, eds., The Book: A Global History, Oxford: Oxford University Press, 39-53.

Kedem Auction House

n.d.a "Miniature Siddur-Amsterdam, 1739-Variant", Books and Manuscripts. https://www.kedem-auctions.com/content/miniature-siddur-amsterdam-1739-variant

n.d.b. "Avraham Haba-Passover Haggadah - Micrography on an Egg".

https://www.kedem-auctions.com/content/avraham-haba-passover-haggadah-micrography-egg

Lévi-Strauss, Claude

1994 Den vilde tanke, København: Gyldendal.

MBS Presentations

n.d. Miniature Book Society. https://www.mbs.org

Morse-Harding, Chloe

2015 "Miniature Books", Brandeis Special Collections Spotlight. http://brandeisspecialcollections.blogspot.dk/2015/07/miniature-books.html

Moyer, Ian S. \& Jacco Dieleman

2003 "Miniaturization and the Opening of the Mouth in a Greek Magical Text (PGM XII.270-350)", Journal of Ancient Near Eastern Religions 3, 47-72. https://doi.org/10.1163/1569212031960320

Nongbri, Brent

2005 “The Use and Abuse of P52: Papyrological Pitfalls in the Dating of the Fourth Gospel", Harvard Theological Review 98/1, 23-48. https://doi.org/10.1017/S0017816005000842

PBS

2008 “Miniature Hebrew Bible, ca. 1850”. http://www.pbs.org/wgbh/roadshow/season/13/dallastx/appraisals/miniature-hebrew-bible -ca-1850--200802A39

Pearson, David

2013 “Bookbinding”, in: Michael F. Suarez, S.J. \& H.R. Woudhuysen, eds., The Book: A Global History, Oxford: Oxford University Press, 245-257.

Reader, Ian

1988 "Miniaturization and Proliferation: A Study of Small-Scale Pilgrimages in Japan", Studies in Central and East Asian Religions 1, 55-66.

Rickard, Kathryn I.

1988 A Lady and Her Books: The Biography of Doris Varner Welsh, Montreal: du Parnasse.

Rivkin, Isaac

1939 "A Pocket Edition Prayer Book for German Jewish Emigrants to America, 1842", American Jewish Historical Society 35, 207-212.

Rizel, Shlomo

2016 "From Auschwitz to Israel, the Saga of a Long-Lost Mini-Torah: How a Journalist Made a Priceless Personal Discovery", Chabad. org News. January 11.

http://www.chabad.org/news/article_cdo/aid/3193812/jewish/From-Auschwitz-to-Israel-theSaga-of-a-Long- Lost-Mini-Torah.htm

Robson, Eleanor

2009 "The Clay Tablet Book in Sumer, Assyria, and Babylonia", in: Simon Eliot \& Jonathan Rose, eds., A Companion to the History of the Book, Oxford: Wiley-Blackwell, 67-83.

https://doi.org/10.1002/9780470690949.ch5 
Roemer, Cornelia

2009 "The Papyrus Roll in Egypt, Greece, and Rome", in: Simon Eliot \& Jonathan Rose, eds., A Companion to the History of the Book, Oxford: Wiley-Blackwell, 84-94. https://doi.org/10.1002/9780470690949.ch6

Sabar, Shalom

2009 "Torah and Magic: The Torah Scroll and Its Appurtenances as Magical Objects in Traditional Jewish Culture", European Journal of Jewish Studies 3/1, 135-170. https://doi.org/10.1163/102599909X12471170467448

Schleicher, Marianne

2009 "Artifactual and Hermeneutical Use of Scripture in Jewish Tradition", in: Craig A. Evans and H. Daniel Zacharias, eds., Jewish and Christian Scripture as Artifact and Canon, London: T\&T Clark, $48-65$.

2010 "Accounts of a Dying Scroll: On Jewish Handling of Sacred Texts in Need of Restoration or Disposal", in: Kristina Myrvold, ed., The Death of Sacred Texts: Ritual Disposal and Renovation of Texts in World Religions, London: Ashgate, 11-29.

2017 "Engaging All the Senses: On Multi-sensory Stimulation in the Process of Making and Inaugurating a Torah Scroll", Postscripts 8/1-2, 39-65. https://doi.org/10.1558/post.32694

Smith, Jonathan Z.

1995 “Trading Places", in: Marvin Meyer and Paul Mirecki, eds., Ancient Magic and Ritual Power, Leiden: Brill, 13-27. https://doi.org/10.1163/9789004283817_003

Stewart, Susan

1993 On Longing: Narratives of the Miniature, the Gigantic, the Souvenir, the Collection, Durham: Duke University Press. https://doi.org/10.1215/9780822378563

Vera, Eugenia Roldán

2013 "The History of the Book in Latin America (including Incas and Aztecs)”, in: Michael F. Suarez, S. J. and H. R. Woudhuysen, eds., The Book: A Global History, Oxford: Oxford University Press, 656-670.

Welsh, Doris V.

1987 The History of Miniature Books. Albany: Fort Orange Press.

Wiseman, Donald J.

1955 “Assyrian Writing-Boards", Iraq 17/1, 3-13. https://doi.org/10.2307/4241713

Woollaston, Victoria

2013 “The World's Oldest Jewish Prayer Book? Hebrew Text Predates Earliest Known Copy of the Torah by Four Centuries", Mail Online, October 2. http://www.dailymail.co.uk/sciencetech/article-2441588/The-worlds-oldest-Jewish-prayer-book-Hebrew-text-predates-earliest-known-copyTorah-CENTURIES.html

World of Judaica

2017 "Sterling Silver 2 Gigabyte Disk on Key with Digital Book of Tehillim". http://www.worldofjudaica.com/jewish-jewelry/necklacespendants/p_925_sterling_silver_8_gigabyte_disk_on_key_with_digital_book_of_tehillim

Yeshiva World

2014 "World's Smallest Torah Scroll Up for Auction". http://www.theyeshivaworld.com/news/headlines-breaking-stories/218946/worlds-smallesttorah-scroll-up-for-auction.html

Znidersic, Martin

2004 "Small is Beautiful (But is It Useful?): Miniature Books through the Ages", Logos 15/3, 144-146. https://doi.org/10.2959/logo.2004.15.3.144

Marianne Schleicher, lektor, ph.d. Afdeling for Religionsvidenskab, Aarhus Universitet 